\title{
A Case of Surgical Treatment of Juvenile Angiofibroma in the Pterygopalatine Fossa with Endoscopic Transmaxillary Surgery Combined with Endoscopic Intranasal Surgery
}

\author{
Keiichi Miyashita, Junichiro Ohori and Yuichi Kurono
}

\begin{abstract}
Juvenile angiofibroma (JAF) is a benign tumor that arises from the sphenopalatine foramen in adolescent males. It accounts for about $0.05 \%$ of all head and neck tumors. JAF manifests with a triad of symptoms, including nasal obstruction, epipharyngeal mass lesion, and recurrent epistaxis. Since this tumor frequently invades the surrounding tissues, causing bony destruction, it is not easy to treat the condition surgically without damaging the oropharyngeal function or aesthetics. Herein, we report the case of an 11-year-old boy with JAF who was successfully treated by endoscopic surgery via the transmaxillary approach combined with endoscopic intranasal surgery. Based on this experience, the advantages and disadvantages of the procedure are discussed.
\end{abstract}

Keywords : juvenile angiofibroma, adolescent male, epistaxis, endoscopic transmaxillary approach

\section{References}

1) Chandler JR, Goulding R, Moskowitz L, et al. : Nasopharyngeal angiofibromas: staging and management. Ann Otol Rhinol Laryngol 93: 322-329, 1984.

2) Radkowski D, McGill T, Healy GB, et al. : Angiofibroma. Changes in staging and treatment. Arch Otolaryngol Head Neck Surg 122: 122-129, 1996.

3) Deguchi K, Fukuiwa T, Saito K, et al. : Application of cyberknife for the treatment of juvenile nasopharyngeal angiofibroma: a case report. Auris Nasus Larynx 29: 395-400, 2002.

4) Sessions RB, Bryan RN, Naclerio RM, et al. : Radiographic staging of juvenile angiofibroma. Head Neck Surg 3: 279-283, 1981.

5) Mann WJ, Jecker P and Amedee RG : Juvenile angiofibromas: changing surgical concept over the last 20 years. Laryngoscope 114: 291-293, 2004.

6) Scholtz AW, Appenroth E, Kammen-Jolly K, et al. : Juvenile nasopharyngeal angiofibroma: management and therapy.
Laryngoscope 111: 681-687, 2001.

7) Andrews JC, Fisch U, Valavanis A, et al. : The surgical management of extensive nasopharyngeal angiofibromas with the infratemporal fossa approach. Laryngoscope 99: 429-437, 1989.

8) Carrau RL, Snyderman CH, Kassam AB, et al. : Endoscopic and endoscopic-assisted surgery for juvenile angiofibroma. Laryngoscope 111: 483-487, 2001.

9) Roger G, Tran Ba Huy P, Froehlich P, et al. : Exclusively endoscopic removal of juvenile nasopharyngeal angiofibroma: trends and limits. Arch Otolaryngol Head Neck Surg 128: 928-935, 2002.

10）花牟礼豊, 田中紀充, 川畑隆之, 他 : 若年性鼻咽㬳血管線 維腫における病期分類別手術法の検討. 日耳鼻会報 108: 513-521, 2005.

11) Hyun DW, Ryu JH, Kim YS, et al. : Treatment outcomes of juvenile nasopharyngeal angiofibroma according to surgical approach. Int J Pediatr Otorhinolaryngol 75: 69-73, 2011.
Department of Otolaryngology, Head and Neck Surgery, Kagoshima University Graduate School of Medical and Dental Sciences
Corresponding Author Address : Keiichi Miyashita

kei1384t@m3.kufm.kagoshima-u.ac.jp 

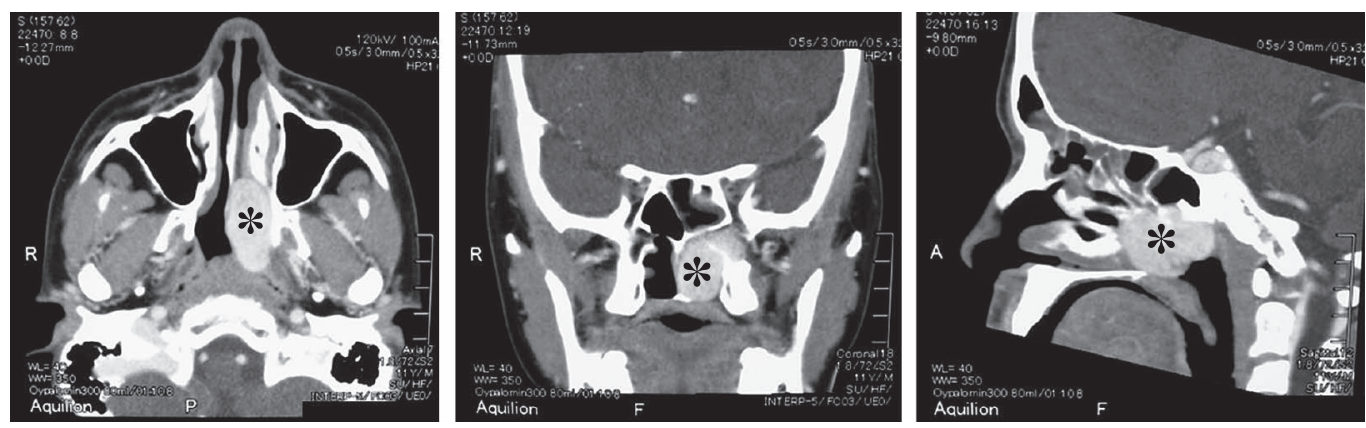

Findings of enhanced head computed tomography

Enhancing tumor lesion (asterisk) showing a clear border against the surrounding tissue, and extending from the posterior part of the nasal cavity to the nasopharynx, also involving the pterygopalatine fossa in part.

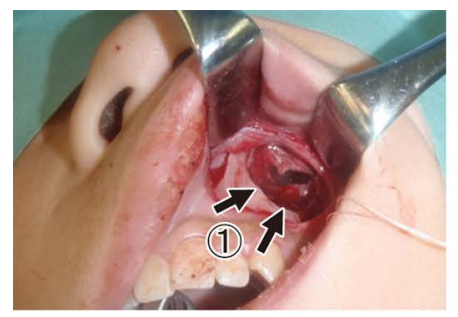

a

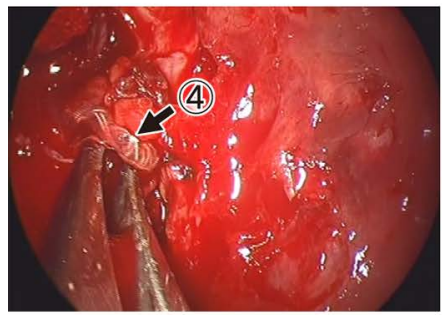

d

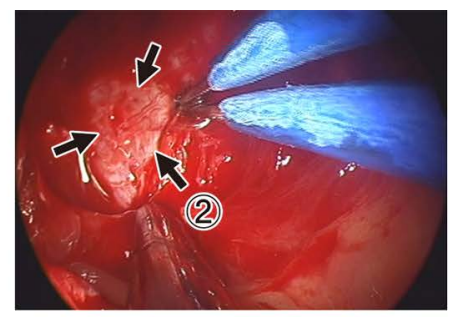

b

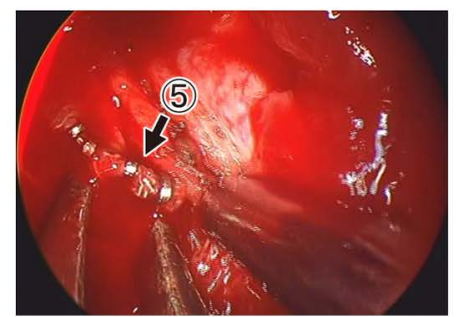

e

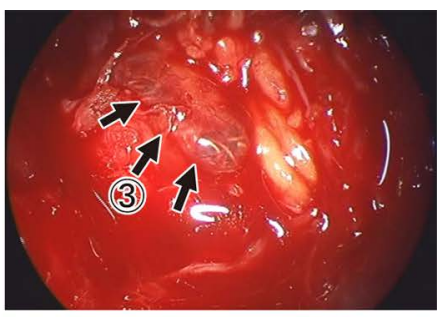

C

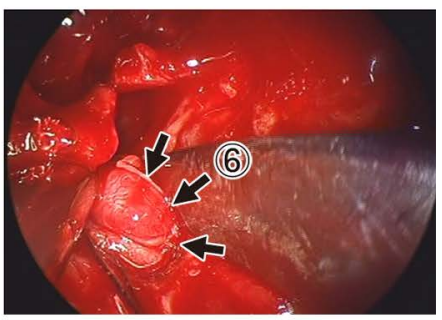

f

Intraoperative findings

a: Opening of the anterior wall of the maxillary sinus

A small opening $(16 \times 10 \mathrm{~mm})$ was made in the anterior wall of the maxillary sinus to obtain minimally invasive access into the maxillary sinus using an endoscope and forceps (endoscopic nasal surgery).

b: Mucosal incision in the posterior wall of the maxillary sinus

An incision was made in the posterior wall of the maxillary sinus under endoscopic guidance.

c: Removal of the posterior bony wall of the maxillary sinus

d: The maxillary artery was embolized with a coil on the day before surgery.

The maxillary artery was observed during the surgical procedure while the tumor was found in the adipose tissue in the pterygopalatine fossa.

e: The maxillary artery was cut after ligation with surgical clips under endoscopic guidance.

f: Tumor with the maxillary sinus mucosa was dissected out of the nasopharynx, and pulled out through the oropharynx and the mouth.

(1) opening of the left canine fossa

(2) opening of the posterior bony wall of the maxillary sinus

(3) exposure of the adipose tissue in the left pterygopalatine fossa

(4)(5) left maxillary artery

(6) main part of the tumor 